\title{
Ibn Thufail's Thought in Hayy ibn Yaqzhan: Psychological Reflection of Soul Development
}

\author{
Choeroni \\ Islamic Studies Department \\ Sultan Agung Islamic University \\ Semarang, Indonesia \\ choeroni@unissula.ac.id
}

\author{
Sholihah \\ Islamic Studies Department \\ Sultan Agung Islamic University \\ Semarang, Indonesia \\ hida@unissula.ac.id
}

\begin{abstract}
Development is also interpreted by progressive and continuous changes in individuals from birth to death. Development can also mean changes experienced by individuals towards the level of maturity that takes place systematically that is mutually influencing between one another, progressively that changes are advanced both psychic and physical, and continuous which means changes that take place regularly, sequentially, it doesn't happen suddenly. This article tries to dissect Ibn Thufail's thoughts in his work Hayy Ibn Yaqzhan which contains the concepts of mental development which are very important for the development of psychology of mental development. This article also evaluates the current tabularasa theory.
\end{abstract}

Keywords- Ibn Thufail, Tabula Rasa Theory, Mental Development

\section{INTRODUCTION}

Development is a change, and this change is not always quantitative, but qualitative. Development is not only emphasized in the material aspect, but in the functional aspect. Changes in a function are caused by a material growth process that allows that function, and besides that, due to changes in learning outcomes. It is not appropriate if we assume that development is merely a change or a psychological process.

Development is also interpreted by progressive and continuous changes in individuals from birth to death. Development can also mean changes experienced by individuals towards the level of maturity that takes place systematically that is mutually influencing between one another, progressively that changes are advanced both psychic and physical, and continuous which means changes that take place regularly, sequentially, it doesn't happen accidentally

Experts argue that in development in general individuals experience a period of shock, if development is described as an evolutionary process, then at the time of the shock evolution turns into a revolution (Yusuf, 2011: 15).

A critical understanding of theories as well as thinkers about theories and approaches is something that must be known and become an inevitable in the study of developmental psychology. Developmental psychology has applied fields, including educational psychology, pediatric clinical psychology, child forensic psychology, as well as other key fields in the field of psychology, including social, cognitive and individual differences (Upton: 2012: 2).
Al Ghazali argued that children who are born carry a balanced and healthy nature. Both parents give religion to them. Child development is strongly influenced by the environment in front of it, in the form of a life style that gives a role to him and from his habits. When born, the child's body is not perfect, the deficiency can be overcome by training and supported by food. Similarly, the nature of children is a gift from the creator. This behavior in an underdeveloped period is still lacking, in this case it can be improved by providing good education to them. Al Ghazali also said that body healing requires a doctor who knows his character, as well as healing the soul and morals. Both require educators who know their nature. The ignorance of the doctor will damage the health of the sick, the ignorance of the educator will damage the student (Yusuf, 2011:10)

This article wants to describe Ibn Thufail's thoughts contained in his work Hayy ibn Yaqzhan as a comparison of tabularasa theory in the science of mental development.

Ibn Thufail is known as one of the multi-disciplinary Islamic philosophers. Aside from being a doctor and government official, Ibn Thufail produced several works that became a source of thought for scientists afterwards.

\section{A GLANCE OF IBUN AL THUFAIL BIOGRAPHY}

The full name of ibn al Thufail was Abu Bakr ibn Abd al Malik ibn Muhammad ibn Thufail. He was born in $506 \mathrm{H} /$ 1110 AD in the city of Cadix Province of Granada, Spain. He is a descendant of a prominent Arab tribe, the Qais. Because of the existence of his family, he has learning facilities from various disciplines that deliver him as a multi-disciplinary scientist, such as medicine, literature, mathematics, and philosophy. In addition, ibn al-Thufail was well known to a philosopher who was able to express his thoughts in an amazing story.

Ibn al Thufail's career began as a famous practicing doctor in Granada, because of his fame, he was appointed as the governor's secretary in the province. Subsequently in $549 \mathrm{H} /$ $1154 \mathrm{AD}$ he was appointed as the personal secretary of Governor Ceuta and Tangier, whose governor was Abd alMu'min who was the first Spanish Muwahhid ruler to capture Morocco in 542 H / 1147 AD. Ibn al-Thufail's highest career was as high doctor and qodli in court and vizier of Caliph Muwahhid Abu Ya'qub Yusuf (558 H / 1163 M-580 H / 1184 
M). coincidentally ibn al Thufail with the Caliph had the same passion in the field of philosophy so that he had the freedom to develop his knowledge with the full support of the government (Sulaiman, 2016 : 93-94)

Because of the advanced age, then in $578 \mathrm{H} / 1182 \mathrm{AD}$ his position as a private doctor of the caliph was replaced by Ibn Rushd, a student and admirer of ibn al Thufail in the field of philosophy, ibn Rushd was also introduced to the caliph by him. Ibn al Thufail died in 581 H / 1185 AD in Morocco which was also attended by the caliph in his funeral (El Ghrari, 2005: 96).

\section{THE WORK OF IBN THUFAIL}

Even though Ibn Thufail was very fond of philosophy and was a multi-disciplinary scholar, he did not produce much writing, this was made possible by his busy positions in various government, as written in his biography, he once pledged as a private doctor of the Caliph, a government doctor, secretary personally the governor, the qodli and the vizier of the khalifah.

Here are some of Ibn al Thufail's scientific works. (1) Muraja'at wa Mabahith, is a work that contains a compilation of the results of the consultations held between ibn al Thufail and ibn Rushd about the prescription of medical drugs, collected by ibn Rusyd in his Generalities, (2) Urjuza fi Tib (a poetry about medical science), this ibn Thufail work was preserved in the al Qaraween library in Fes, Morocco, (3) Haiyy Ibn Yaqdhan. This work is a work that is very famous and inspires scientists and philosophers. This book contains a story of philosophy in which ibn al-Thufail devotes his philosophical knowledge to a narrative story, with his ability to try to integrate philosophy and religion. This work is very well known in the West and is widely translated into various languages including Hebrew, English, French and German (El Ghrari, 2005: 98). This third work is the subject of this article and how the philosophy of Ibn Thufail conveyed his thoughts regarding mental development.

\section{IBN AL THUFAIL'S PHILOSOPHY IN THE WORK OF HAYY IBN YAQZHAN}

Hayy ibnu Yaqdzan by ibn al Thufail was described as a baby boy who was on an island that had never been inhabited by humans. He was a baby from a legitimate marriage secretly between a king's sister and a member of the royal family on another island. Because of fear of the king, the baby is put in a chest and floating floating in the sea. The floating coffin was carried away to the island called wak wak, the floating baby met a deer who had just lost his child who was then cared for and cared for. The baby continues to live in an animal environment and can develop well into a different human being from animals (Sulaiman, 2016: 94-95).

Furthermore, the complete story of Hayy ibn Yaqdzan's life is divided into seven phases to meet Isal and Salaman. The first phase starts from parenting, guarding and protecting the mother deer to a small hay of seven years, she has been able to distinguish animal sounds and is able to count them. In addition, he also began to recognize his nakedness and looked for sticks as material to protect himself and maintain his food.

The second phase begins with the deer's death. He searched for the cause of the death of his mother, he had a parent surgery until he was able to draw the conclusion that what moved his mother was something that resided in his heart. If what is in his heart goes out, the mother will die and be unable to move again. From this incident Hayy understands that there are two sources of knowledge, namely the senses and experiments. Then he began to divide the types of body members and their respective tasks as well as something that moved them.

The third phase starts when he finds fire, from how to get it to how to use it. From his discovery of fire, he began to learn about the hayawani spirit that resides in the body. The fourth phase, he began to recognize objects in nature (creation) and natural bodies (objects), he began to recognize single objects and compounds as well as spirits. He is able to divide objects into two traits namely light and heavy, also the suitability of matter and shape in the universe to find the cause of the creation of objects. Until he is twenty years old (Tufail, 2010: 4).

The fifth phase begins when he observes things on earth, he observes stars, according to his observations the stars are finite. From these observations, the question began to arise whether nature is qadim or new? This thought arises when Hayy is 35 years old, age for thinking maturity. The sixth phase, began to emerge when Hayy began to think of the existence of a Supreme Being, according to him the spirit was separate and different from the body, there was no connection between the spirit and the objects around, according to him the spirit was directly related to the creator. According to him, eternal happiness will be realized if the eternal soul is able to witness the creator (al Musyahadah bi al Wajibul Wujud). When that can be realized, eternal happiness will be created.

In the seventh phase, this phase can be realized if Hayy is able to worship with al Wajibul Wujud continuously, then his soul will get salvation and happiness. After that Hayy divided it into three stages. In the first phase, Hayy provides restrictions and provisions for his body. He ate only enough food not excessive so as not to disobey the blessings of Allah. The second stage, Hayy took steps to resemble the rotation of the planets of the stars, he putari the hill in exactly located. After that, he circled himself according to the rotation of the planets of the stars until he collapsed.

After that, he arrived at the third stage. After waking up he saw the stars glowing, then he began to cleanse his body. Then he continues to think of al Wajibul Wujud and sever the relationship with the universe. He closed his eyes, he blew his ears, he blocked the phonals that bothered him to pray with al Wajibul Wujud by turning around and moving fast until everything in this world became dead. His life became weak, he cleared his mind of disgrace and filth so that he was able to worship directly with al Wajibul Wujud. At that time, he witnessed something that was not seen by the eye, not heard by the ears, not crossing the human mind. That armpit, he feels that the essence is the essence of God. He has merged with the essence of God (Tufail, 2010: 5-7).

In the work of ibn al Thufail, Hayy Bin Yaqdzan there are three characters who symbolize three ways of life, namely:

1. Hayy Bin Yaqdzan, symbol of the life of a philosopher (true philosopher). He thought about nature and wanted everything, thinking of himself, who finally thought of God. 
2. Absal, the symbol of the life of a religious expert. By thinking of revelation as truth finally comes to the belief of the existence of God.

3. King Salaman and his people, the symbol of life from the world. They know the Tunah from their teacher, they only come to the final faith not to the ultimate belief. Therefore, their lives are covered by temporal lust, love of wealth, love of pleasure and throne (Sulaiman, 2016: 96).

\section{THEORY IN DEVELOPMENT PSYCHOLOGY}

Humans are the most perfect creatures compared to other creatures. In its development, humans are greatly influenced by their surroundings, humans are also influenced by abilities that exist in themselves. Humans are creatures that are dynamic towards changes that occur, especially changes from time to time (walgito, 2004: 44).

Regarding the factors that determine human development, there are some opinions from experts who also bring up several theories including;

1. Nativism Theory. The theory stated by Schopenhouer states that human development is determined by hereditary factors carried by individuals at birth. While other factors, namely environment and education have little effect on individual development. In this theory, human development is determined by the nature inherited by their parents. If the parents are good, then they will be good, too if their parents are bad, they will grow up and have bad characteristics and cannot be changed by the environment or education. In this theory, environment and education are powerless in the the case of human development, because in its development it is always determined by the good and bad of the descendant that preceded it (Walgito, 2004: 45)

2. The theory of empiricism. This theory is an extension of John Locke's tabular rasa theory. This theory states that the development of an individual is strongly influenced by the experience of experience gained during the development of the individual including the educational factors he received. According to this theory, a baby was born in an empty state like white paper, various ideas in the mind of each person actually come from experiences obtained through the five senses (Juhari 2013: 5), depending on what is written on it, therefore the role of the environment and the education is very large, the environment and the educator determine the circumstances of the individual in the future (Walgito, 2004: 46). This theory is very contrary to the previous theory, which states that descendant is a major factor in individual development, whereas this theory states that experience, environment and education are the main factors in individual development. John Lock's empirical theory is in line with the understanding of Helvatus, a Greek philosopher who argues that humans are born with almost the same soul and character, namely clean and holy. It is education and the environment that will influence children as they want. The environment includes family, school, community, human environment, geography, culture, religion, and so on (Nata, 2013: 243-144).

3. Convergent theory (Combined). This theory was put forward by W. Stern who stated that gen and environment have an important role in individual development. The development of individuals will be determined both by factors that are born at birth (endogenous factors) and environmental factors (including experience and education) which are exogenous factors. This theory can be accepted by experts in general. This theory has been tested by W. Stern with a study of two twins who were separated from their partners and placed in places that had different influences. After a long time from the separation it turns out that the two children have different characteristics from each other even though they were born from one descendant. This is caused by environmental factors that affect the child (Walgito, 2001: 48).

\section{IBN THUFAIL'S SOUL DEVELOPMENT THEORY AND TABULARASA THEORY}

We have known that Ibn al Thufail lived in the golden age of Islam, namely in the year $506 \mathrm{H} / 1110 \mathrm{M}-581 \mathrm{H} / 1185$ $\mathrm{AD}$ with the phenomenal work of Hayy Bin Yaqdzan which influenced Muslim thinkers or Westerners afterwards. Hayy Bin Yaqdzan contains the story of a wasted person on an island without human inhabitants, who was finally raised by a deer. It is known that the development of Hayy Bin Yaqdzan's life through seven phases, between one and the other, complement each other and finally reach the ultimate end of life. This work was then explored, adapted and adopted by some Western scientists with various stories and media. Indeed, at a glance Hayy's story seemed to tell a person in an empty state who grew up with experience and the environment to achieve his life goals. This is also in harmony with the hadith of the Prophet.

"From Abi al-Zinad, from al-A'raj from Abi Hurairah, indeed the Messenger of Allah SAW said that everyone born must be born of fithrah. His parents made him a Jew, the Nazarani, just as camels were born from perfect animals. Do you expect an imperfect birth to his limbs? The Companion asked: $\mathrm{O}$ apostle, do you not see the dead when you were little? He said: Allah knows all they do. (HR. Malik)

The Qur'an also explains about human development very clearly in several verses, one of which is as the Word of God Almighty.

It is He who created you from dust, then from a seed, then from an embryo, then He brings you out as an infant, then $\mathrm{He}$ lets you reach your maturity, then you become elderlyalthough some of you die sooner-so that you may reach a predetermined age, so that you may understand (QS: Ghofir 67).

While John Locke was born in $1632 \mathrm{AD}$ at the same time as his life was influenced by the philosophy of ibn al Thufail, namely; George Keith, William Penn, Gottfried William Leibniz, Alexsender Pope, Daniel Defoe, Simon Ockley, 
Voltaire, Jean Jacques Rousseau. In my opinion John Locke may also be influenced by the philosophical theory developed by ibn al Thufail through the work of Hayy which has been adapted and adopted by Western scientists.

In the concept of ibn al Thufail, in fact the first stage of the soul is not a tabularasa or a blank blackboard, the image of God has been implied in it from the beginning, but to make it appear real, ibn Thufail needs to start with a clear mind without prejudice from the prejudice and social tendencies as conditions the beginning of all knowledge, was the real idea behind Hay's sudden birth on an empty island. After this experience is achieved, intelligence and execution play freely their role in sequence in providing a clear vision of the truth inherent in the soul. Not just mental discipline, but the sense and reason education needed to get such a vision. Conformity between experience and reason, on the one hand, and the fit between reason and intuition (Mustofa, 1997: 278).

According to the author, that the tabularasa theory captures human development in terms of material only, that babies are born in a state of pure white like white paper, various scribbles that depend on the culprit, as well as various ideas that exist in the mind of each person actually comes from experience gained through five sense. This theory denies the existence of divine intervention in the development of the individual, even though the imagination of God has been implied since the beginning of the creation of each individual.

\section{CONCLUSION}

Ibn al Thufail is a multi-disciplinary Muslim scientist. Not much of the work produced might be due to his business in the field of government. Even so, the work produced turned out to provide a lot of inspiration and great influence for scientists afterwards. They translated, adapted and even adopted his work. In the psychology of human development, his work with the theme of Hayy Bin Yaqdzan was very inspiring for other scientists, not least perhaps the tabularasa theory developed by John Locke who took the side of sensory development. Although according to the opinion of the author of ibn al-Thufail's account through the story of Hayy Bin Yaqdzan the first stage of the soul is not a tabularasa or a blank blackboard, the image of God has been implied in it from the beginning and its development also has a purpose to unite with the Wajibul Wujud.

\section{REFERENCES}

[1] Daudi, A. (1986) Kuliah Filsafat Islam. Jakarta: Bulan Bintang.

[2] Ghrari, H. (2005) Para Pelopor Peradaban Islam. Yogjakarta: PT. Mitra Aksara Mulia.

[3] Juhari (2013) Muatan Sosiologi dalam Pemikiran Filsafat John Locke. Jurnal Al-Bayan, VOL. 19, NO. 27, 5.

[4] Masyhur, K. (1986) Meninjau Berbagai Ajaran; budi pekerti / etika dengan ajaran Islam. Jakarta, Kalam Mulia.

[5] Mustofa (1997) Filsafat Islam. Bandung: Pustaka Setia.

[6] Nasution, H., (1986) Teologi Islam : Aliran-aliran sejarah Analisa Perbandingan. Jakarta: UI-Press.

[7] Nasution, H. ( 1999). Filasafat Islam. Jakarta: Gaya Media Pratama.

[8] Nata, A. (2013) Pemikiran Pendidikan Islam dan Barat. Jakarta: Rajawali Press.

[9] Sulaiman, A. (2016). Mengenal Filsafat Islam, Bandung: Yrama Widya.

[10] Thufail, A., B., M. (2010) Hayy Bin Yaqdzan, Manusia dalam Asuhan Rusa. Yogjakarta: Navila

[11] Upton, P. (2012) Psikologi Perkembangan. Jakarta: Erlangga.

[12] Walgito, B (2004). Pegantar Psikologi Umum. Yogjakarta: Andi Offset.

[13] Yusuf, Syamsu. (2011)Psikologi Perkembangan Anak \& Remaja, (Bandung: PT. Remaja Rosdakarya, 2011). 